\title{
Effect of Sulphur Dioxide Pads on Enhancement of Shelf Life of Strawberry (Fragaria ananassa) under Ambient Condition
}

\author{
Sayed Samiullah Hakimi $^{1 *}$, K.N. Sreenivas ${ }^{2}$, T.H. Shankarappa ${ }^{3 *}$, \\ H.C. Krishna ${ }^{2}$ and G.K. Sadananda ${ }^{2}$ \\ ${ }^{1}$ Department of Horticulture, Faculty of Agriculture, Kabul University, Afghanistan \\ ${ }^{2}$ Department of Postharvest Technology, College of Horticulture, UHS Campus, GKVK, \\ Bengaluru- 560 065, Karnataka, India \\ ${ }^{3}$ College of Horticulture, Kolar, 563 102, Karnataka, India \\ *Corresponding author
}

\begin{tabular}{|c|c|}
\hline & A B S T R A C T \\
\hline Keywords & \multirow{4}{*}{$\begin{array}{l}\text { The research was carried out to study the effect of sulphur dioxide pads on } \\
\text { shelf life of strawberry (Fragaria ananassa) under ambient condition ( } 24 \pm \\
26^{\circ} \mathrm{C} \text { ) with six treatments. } \mathrm{SO}_{2} \text { pads containing different mixtures of KMS } \\
\text { and citric acid had no significant effect on the shelf life of strawberry. All } \\
\text { the treatments, control as well as sulphur dioxide pads containing varied } \\
\text { levels of } \mathrm{SO}_{2} \text { between } 400 \text { ppm and } 2000 \mathrm{ppm} \text { were found on par with one } \\
\text { other for shelf life of strawberry fruits under ambient condition. Thus the } \\
\text { use of } \mathrm{SO}_{2} \text { pads had not prolonged shelf life of strawberry fruits and } \\
\text { spoilage occurred in all the treated and controlled fruits within } 4 \text { days of } \\
\text { storage. }\end{array}$} \\
\hline $\begin{array}{l}\text { Ambient } \\
\text { condition, KMS, } \\
\mathrm{SO}_{2} \text { releasing pad, } \\
\text { Shelf life and } \\
\text { Strawberries. }\end{array}$ & \\
\hline Article Info & \\
\hline $\begin{array}{l}\text { Accepted: } \\
\text { 26 June } 2017 \\
\text { Available Online: } \\
\text { 10 July } 2017\end{array}$ & \\
\hline
\end{tabular}

\section{Introduction}

Strawberry (Fragaria x ananassa Duch) belongs to the family of Rosaceae which is one of the most important temperate fruit crops. The cultivated strawberry (Fragaria $\mathrm{x}$ ananassa Duch.) is a result of hybridization of two Native American species F. chiloensis (L) Duch. and F. virginiana Duch (Prakash, 1997).

Strawberry fruits are economically and commercially important and widely consumed as fresh or in processed forms, such as jams, juices, and jellies (Prakash, 1997). Because strawberry has high nutritive value which is rich in vitamins such as vitamin C (58.8 mg $\left.100 \mathrm{~g}^{-1}\right)$, thiamine $(0.024$ $\left.\mathrm{mg} 100 \mathrm{~g}^{-1}\right)$, niacin $\left(0.386 \mathrm{mg} 100 \mathrm{~g}^{-1}\right)$ and minerals like calcium $\left(16 \mathrm{mg} 100 \mathrm{~g}^{-1}\right)$, iron (0.41 mg $\left.100 \mathrm{~g}^{-1}\right)$, magnesium (13 mg $\left.100 \mathrm{~g}^{-1}\right)$, phosphorus (24 mg $100 \mathrm{~g}^{-1}$ ) and potassium (153 mg $\left.100 \mathrm{~g}^{-1}\right)$. In addition to that, it has energy $\left(32 \mathrm{kcal} 100 \mathrm{~g}^{-1}\right)$, protein $\left(0.67 \mathrm{~g} 100 \mathrm{~g}^{-}\right.$ $\left.{ }^{1}\right)$, carbohydrates $\left(7.68 \mathrm{~g} 100 \mathrm{~g}^{-1}\right)$ and sugars

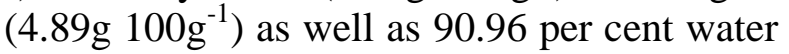
content. The red colour of the strawberry is because of one of the important phytochemical in the form of anthocyanin, present in fresh fruits and its values ranges 
from 150 to $600 \mathrm{mg} \mathrm{kg}^{-1}$ total anthocyanin contents (Giampieri et al., 2012).

Because of high moisture and high acidity contents strawberry are highly susceptible to fungal diseases and spoil within short period of time, hence less storage life. Strawberry fruits need to be harvested carefully and all the postharvest practices as packaging, transportation and handling have to be performed based on standard procedure accordingly (Zhang et al., 2007). Some of the chemicals such as $\mathrm{SO}_{2}$ and citric acid were used at varying levels to regulate the spoilage of strawberry fruits under refrigerated condition (Samiullah et al., 2015). Sulphur dioxide reacts with water content of product and forms sulphurous acid at low pH (Rajesh, 1993). Sulphurous acid $\left(\mathrm{H}_{2} \mathrm{SO}_{3}\right)$ react with cell membrane and block enzymes of the microorganism by reducing essential disulphide (-S-S-) linkage. Therefore inhibits the multiplication of microorganisms (Verma and Joshi, 2006). Hence, the investigation was conducted under ambient condition with use of sulphur dioxide pads on strawberries to minimize the postharvest decay and extend their shelf life.

\section{Materials and Methods}

The study on "Effect of sulphur dioxide pad on enhancement of shelf life of strawberry (Fragaria ananassa)" under ambient condition was carried out in the Department of Postharvest technology, College of Horticulture, University of Horticultural Sciences Campus, Gandhi Krishi Vigyana Kendra (PO), Bengaluru- 560065, Karnataka, India during the year 2013-2014.

The (Dimonte) cultivar of strawberry fruits procured from the Namdhari farm, Arkadu, Ooty, Tamil Nadu had been subjected for the study. Fruits were harvested at white tip stage of maturity in the early hours of morning and then transported through good transportation system. The fruits were subjected to treatment at lapsed time of 24 hours from the harvesting and on arrival at laboratory once again sorted (to remove misshaped, bruised, diseased and insect infected fruits) and graded for homogeneity of the experiment.

Sulphur dioxide pads were prepared from brown laminated paper which was essentially of quick release formulation. These guards were designed to release $\mathrm{SO}_{2}$ gas within 24 48 hours of packing with strawberry.

The brown laminated paper was first cut into $14 \mathrm{~cm} \times 11 \mathrm{~cm}$ sheets divided into 4 quarters per packet and they were sealed using an impulse heat sealing machine (SEPACK, India). The calculated amount of potassium metabisulphite (KMS) + citric acid (CA) was weighed and sealed in small packets.

Corrugated fiber board (CFB) boxes with dimensions of $15.50 \mathrm{~cm} \times 12.50 \mathrm{~cm} \times 9 \mathrm{~cm}$ bearing capacity to accommodating $500 \mathrm{~g}$ strawberries were used as a packaging material. These boxes had single 0.5" diameter holes punched at each side of the boxes.

The folded boxes were first opened up and the bottom closed and sealed with tape. The boxes were then lined with 1 layer of crepe paper (as cushion) with enough crepe paper left on the top to be used as flap for folding over the strawberries.

The boxes were lined with crepe paper both lengthwise and breadth wise. In each boxes $500 \mathrm{~g}$ of strawberry fruits were placed and the strawberry guard was placed onto the fruits. The crepe papers were folded over and the boxes sealed with sealing tape (Samiullah et al., 2015).

The sulphur dioxide pad formulation consisted of two chemicals namely potassium metabisulphite (KMS) and citric acid (CA) 
were mixed in the ratio of 10: 6 to prepare quick release formulation. The quick release formulation was prepared by mixing $100 \mathrm{~g}$ KMS and 60 g citric acid.

The efficacy of sulphur pads was tested using a complete randomized design with six treatments. Five treatments had $\mathrm{SO}_{2}$ pads made up of mixture of KMS and citric acid @ 0.2g (400 ppm $\mathrm{SO}_{2}$ ), 0.4g (800 ppm $\mathrm{SO}_{2}$ ), 0.6g (1200 ppm SO $\mathrm{SO}_{2}$, 0.8g (1600 ppm $\mathrm{SO}_{2}$ ), and $1.0 \mathrm{~g}\left(2000 \mathrm{ppm} \mathrm{SO}_{2}\right)$, and one control ((zero ppm $\left.\mathrm{SO}_{2}\right)$. The treatments were replicated four times and conducted under ambient condition $\left(24 \pm 2^{0} \mathrm{C}\right)$.

The parameters like TSS, titratable acidity, reducing sugar, total sugar, ascorbic acid, anthocyanin content, Cumulative Physiological Loss of Weight, firmness and decay loss were estimated by using standard procedures (Srivastava and Kumar, 2012 ; Khezrzadeh et al., 2013). The sensory evaluation has done by using composite scoring test (Verma and Joshi, 2006).

\section{Results and Discussion}

Sulphur dioxide pads used to study their efficacy on decay control and also their effect on various physicochemical and quality attributes on fresh strawberries under ambient condition.

Study reveal that $\mathrm{SO}_{2}$ pads had not showed significant effect on the shelf life of fruits as compared to the control and recorded continuous changes in physico-chemical parameters compared to initial data such as TSS $\left(4.20^{\circ} \mathrm{B}\right)$, titratable acidity $(0.200 \%)$, reducing sugar $(2.13 \%)$, total sugar $(2.78 \%)$, ascorbic acid $\left(59.0 \mathrm{mg} 100 \mathrm{~g}^{-1}\right)$, anthocyanin

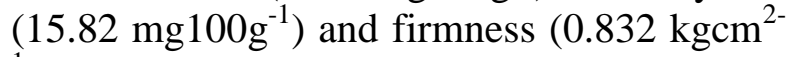
$\left.{ }^{1}\right)$ (Giampirie et al., 2012). Results indicated that there was a continuous loss in weight and decay loss of the strawberries (Table 1) during storage. Significant differences in
CPLW, decay losses and fruit firmness were not noticed among the treatments. The fruits treated with sulphur dioxide pads did not showed minimum loss in weight and decay losses and also high firmness as compared to control (without $\mathrm{SO}_{2}$ pad), recorded on $\left(1^{\text {st }}\right.$, $2^{\text {nd }}$ and $3^{\text {rd }}$ days respectively) (Krishnan, 2001; Shin et al., 2008).

The data revealed that, the total soluble solids (TSS) had increased up to the last day of storage and not decreased as storage progressed (Table 2).

$\mathrm{SO}_{2}$ pads did not have a significant effect on tiratable acidity of strawberries and its content decreased continuously till end of storage (Jouki and Khazaei, 2012; Samiullah et al., 2015).

Significant differences in reducing sugar and also total sugar of strawberries was not observed among the treated and control units of strawberry recorded on $1^{\text {st }}, 2^{\text {nd }}$ and $3^{\text {rd }}$ days of storage respectively (Table 3 ).

Similar decreasing of reducing sugar and total sugars observed in all treatments and control units of strawberries until the end of shelf life of fruits (Cordenunsi, 2003; Nielsen and Leufven, 2008).

Ascorbic acid content of the strawberry fruits had decreased during storage period. The $\mathrm{SO}_{2}$ pads had not have a significant effect on ascorbic acid content of strawberries as compared with control during three days of storage (Table 4).

Also the anthocyanin content of strawberries had increased during storage period. And there was not significant effect of $\mathrm{SO}_{2}$ pads to maintain lowest content of anthocyanin in strawberries during storage period (Table 4) (Holcroft and Kader, 1999; Cordenunsi, 2003; Wang and Gao, 2013). 
Table.1 Effect of different concentrations of sulphur dioxide pads on physiological properties of Strawberry fruits stored under ambient condition

\begin{tabular}{|c|c|c|c|c|c|c|c|}
\hline \multirow[t]{2}{*}{ Treatments } & \multicolumn{3}{|c|}{ PLW (\%) on storage days } & \multicolumn{3}{|c|}{$\begin{array}{c}\text { Decay loss (\%) on storage } \\
\text { days }\end{array}$} & \multirow{2}{*}{$\begin{array}{c}\begin{array}{c}\text { Firmness } \\
\left(\mathrm{Kgcm}^{-2}\right)\end{array} \\
3^{\text {rd day }}\end{array}$} \\
\hline & $1^{\text {st }}$ day & $2^{\text {nd }}$ day & $3^{\text {rd day }}$ & $1^{\text {st day }}$ & $2^{\text {nd }}$ day & $3^{\text {rd day }}$ & \\
\hline $\mathrm{T}_{1}$ : Control & 3.00 & 5.05 & 9.38 & 15.48 & 26.25 & 41.18 & 0.64 \\
\hline $\begin{array}{l}\mathrm{T}_{2}: 0.2 \mathrm{~g}(\mathrm{KMS}+ \\
\text { Citric acid) }\end{array}$ & 2.90 & 4.62 & 9.17 & 12.53 & 26.18 & 41.30 & 0.64 \\
\hline $\begin{array}{l}\mathrm{T}_{3}: 0.4 \mathrm{~g}(\mathrm{KMS}+ \\
\text { Citric acid) }\end{array}$ & 2.93 & 5.19 & 9.42 & 13.85 & 26.75 & 41.13 & 0.64 \\
\hline $\begin{array}{l}\mathrm{T}_{4}: 0.6 \mathrm{~g}(\mathrm{KMS}+ \\
\text { Citric acid) }\end{array}$ & 2.87 & 4.83 & 9.25 & 11.63 & 26.53 & 40.70 & 0.63 \\
\hline $\begin{array}{l}\mathrm{T}_{5}: 0.8 \mathrm{~g}(\mathrm{KMS}+ \\
\text { Citric acid) }\end{array}$ & 2.82 & 4.95 & 9.23 & 7.85 & 25.05 & 41.15 & 0.66 \\
\hline $\begin{array}{l}\mathrm{T}_{6}: 1.0 \mathrm{~g}(\mathrm{KMS}+ \\
\text { Citric acid) }\end{array}$ & 2.65 & 5.15 & 9.08 & 5.48 & 25.38 & 41.70 & 0.66 \\
\hline S. Em \pm & 0.165 & 0.279 & 0.272 & 0.437 & 0.456 & 0.794 & 0.022 \\
\hline CD @ $1 \%$ & 0.671 & 1.137 & 1.109 & 1.781 & 1.859 & 2.525 & 0.091 \\
\hline
\end{tabular}

Initial PLW $=0.00 \%$; Initial decay loss $=0.0 \%$;

Initial firmness $=0.832 \mathrm{kgcm}^{-2} ;$ KMS: Citric Acid @ 10: 6

Table.2 Effect of different concentrations of sulphur dioxide pads on biochemical properties of Strawberry fruits stored under refrigerated condition

\begin{tabular}{|c|c|c|c|c|c|c|}
\hline \multirow{2}{*}{ Treatments } & \multicolumn{3}{|c|}{ TSS ( ${ }^{0}$ Brix) on storage days } & \multicolumn{3}{|c|}{$\begin{array}{c}\text { Titratable acidity }(\%) \text { on } \\
\text { storage days }\end{array}$} \\
\hline & $1^{\text {st }}$ day & $2^{\text {nd }}$ day & $3^{\text {rd }}$ day & $1^{\text {st }}$ day & $2^{\text {nd }}$ day & $3^{\text {rd }}$ day \\
\hline $\mathrm{T}_{1}$ : Control & 4.98 & 6.03 & 4.53 & 0.153 & 0.138 & 0.119 \\
\hline $\begin{array}{l}\mathrm{T}_{2}: 0.2 \mathrm{~g}(\mathrm{KMS}+\text { Citric } \\
\text { acid) }\end{array}$ & 4.93 & 6.05 & 4.68 & 0.176 & 0.135 & 0.118 \\
\hline $\begin{array}{l}\mathrm{T}_{3}: 0.4 \mathrm{~g}(\mathrm{KMS}+\text { Citric } \\
\text { acid) }\end{array}$ & 4.78 & 5.98 & 4.68 & 0.137 & 0.157 & 0.118 \\
\hline $\begin{array}{l}\mathrm{T}_{4}: 0.6 \mathrm{~g}(\mathrm{KMS}+\text { Citric } \\
\text { acid) }\end{array}$ & 4.40 & 5.85 & 4.70 & 0.176 & 0.148 & 0.118 \\
\hline $\begin{array}{l}\mathrm{T}_{5}: 0.8 \mathrm{~g}(\mathrm{KMS}+\text { Citric } \\
\text { acid) }\end{array}$ & 4.63 & 5.95 & 4.70 & 0.188 & 0.149 & 0.121 \\
\hline $\begin{array}{l}\mathrm{T}_{6}: 1.0 \mathrm{~g}(\mathrm{KMS}+\text { Citric } \\
\text { acid) }\end{array}$ & 4.68 & 5.90 & 4.95 & 0.194 & 0.145 & 0.120 \\
\hline S. Em \pm & 0.121 & 0.198 & 0.116 & 0.006 & 0.006 & 0.002 \\
\hline CD@1\% & 0.493 & 0.809 & 0.473 & 0.026 & 0.025 & 0.008 \\
\hline
\end{tabular}

Initial TSS $=4.20^{0}$ Brix;

Initial titratable acidity $=0.20 \%$;

KMS: Citric Acid @ 10:6 
Table.3 Effect of different concentrations of sulphur dioxide pads on reducing and Total sugars of strawberry fruits stored under ambient condition

\begin{tabular}{|c|c|c|c|c|c|c|}
\hline \multirow[t]{2}{*}{ Treatments } & \multicolumn{3}{|c|}{$\begin{array}{c}\text { Reducing sugars (\%) on } \\
\text { storage days }\end{array}$} & \multicolumn{3}{|c|}{$\begin{array}{c}\text { Total sugars (\%) on storage } \\
\text { days }\end{array}$} \\
\hline & $1^{\text {st }}$ day & $2^{\text {nd }}$ day & $3^{\text {rd }}$ day & $1^{\text {st }}$ day & $2^{\text {nd }}$ day & $3^{\text {rd }}$ day \\
\hline $\mathrm{T}_{1}:$ Control & 3.23 & 3.50 & 3.08 & 3.78 & 3.87 & 3.57 \\
\hline $\begin{array}{l}\mathrm{T}_{2}: 0.2 \mathrm{~g}(\mathrm{KMS}+\text { Citric } \\
\text { acid) }\end{array}$ & 3.28 & 3.50 & 3.10 & 3.83 & 4.03 & 3.71 \\
\hline $\begin{array}{l}\mathrm{T}_{3}: 0.4 \mathrm{~g}(\mathrm{KMS}+\text { Citric } \\
\text { acid) }\end{array}$ & 3.30 & 3.48 & 3.20 & 3.60 & 3.89 & 3.69 \\
\hline $\begin{array}{l}\mathrm{T}_{4}: 0.6 \mathrm{~g}(\mathrm{KMS}+\text { Citric } \\
\text { acid) }\end{array}$ & 3.28 & 3.53 & 3.17 & 3.60 & 3.93 & 3.67 \\
\hline $\begin{array}{l}\mathrm{T}_{5}: 0.8 \mathrm{~g}(\mathrm{KMS}+\text { Citric } \\
\text { acid) }\end{array}$ & 3.43 & 3.60 & 3.12 & 3.66 & 3.91 & 3.71 \\
\hline $\begin{array}{l}\mathrm{T}_{6}: 1.0 \mathrm{~g}(\mathrm{KMS}+\text { Citric } \\
\text { acid) }\end{array}$ & 3.45 & 3.55 & 3.20 & 3.70 & 3.90 & 3.68 \\
\hline S. Em \pm & 0.125 & 0.086 & 0.131 & 0.091 & 0.085 & 0.119 \\
\hline $\mathrm{CD} @ 1 \%$ & 0.512 & 0.350 & 0.536 & 0.370 & 0.346 & 0.487 \\
\hline
\end{tabular}

Initial reducing sugars $=2.13 \%$; Initial total sugars $=2.78 \%$; KMS: Citric Acid @ 10: 6

Table.4 Effect of different concentrations of sulphur dioxide pad on ascorbic acid and Anthocyanin content of strawberry fruits stored under ambient condition

\begin{tabular}{|c|c|c|c|c|}
\hline \multirow[t]{2}{*}{ Treatments } & \multicolumn{3}{|c|}{ Ascorbic acid $\left(\mathrm{mg100g}^{-1}\right)$} & \multirow{2}{*}{$\begin{array}{c}\begin{array}{c}\text { Anthocyanin } \\
\left(\mathrm{mg100g}^{-1}\right)\end{array} \\
\mathbf{3}^{\text {rd day }} \\
\end{array}$} \\
\hline & $1^{\text {st }}$ day & $2^{\text {nd }}$ day & $3^{\text {rd }}$ day & \\
\hline $\mathrm{T}_{1}$ : Control & 58.04 & 57.31 & 55.75 & 33.89 \\
\hline $\mathrm{T}_{2}: 0.2 \mathrm{~g}(\mathrm{KMS}+$ Citric acid) & 58.18 & 57.68 & 56.00 & 34.50 \\
\hline $\mathrm{T}_{3}: 0.4 \mathrm{~g}(\mathrm{KMS}+$ Citric acid $)$ & 58.12 & 57.68 & 55.88 & 33.85 \\
\hline $\mathrm{T}_{4}: 0.6 \mathrm{~g}(\mathrm{KMS}+$ Citric acid $)$ & 58.13 & 58.05 & 55.96 & 34.30 \\
\hline $\mathrm{T}_{5}: 0.8 \mathrm{~g}(\mathrm{KMS}+$ Citric acid $)$ & 57.98 & 57.97 & 55.85 & 34.20 \\
\hline $\mathrm{T}_{6}: 1.0 \mathrm{~g}(\mathrm{KMS}+$ Citric acid $)$ & 58.35 & 57.78 & 55.70 & 34.23 \\
\hline S. Em \pm & 0.251 & 0.137 & 0.261 & 0.461 \\
\hline CD@1\% & 1.025 & 0.557 & 1.064 & 1.877 \\
\hline
\end{tabular}

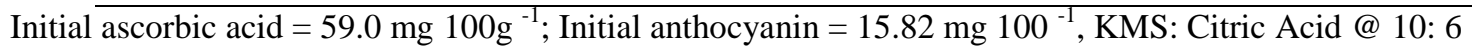

Table.5 Effect of different concentrations of sulphur dioxide pad on sensory traits of strawberry Fruits stored under ambient condition at $3^{\text {rd }}$ day of storage

\begin{tabular}{lcccccc}
\hline \multicolumn{1}{c}{ Treatments } & Colour & Taste & Texture & Flavour & $\begin{array}{c}\text { Absence of } \\
\text { defects }\end{array}$ & $\begin{array}{c}\text { Total } \\
\text { scores }\end{array}$ \\
\hline $\mathrm{T}_{1}:$ Control & 13 & 12 & 12 & 13 & 13 & 63 \\
$\mathrm{~T}_{2}: 0.2 \mathrm{~g}(\mathrm{KMS}+$ Citric acid) & 13 & 13 & 13 & 14 & 12 & 65 \\
$\mathrm{~T}_{3}: 0.4 \mathrm{~g}(\mathrm{KMS}+$ Citric acid) & 14 & 13 & 12 & 13 & 13 & 65 \\
$\mathrm{~T}_{4}: 0.6 \mathrm{~g}(\mathrm{KMS}+$ Citric acid) & 12 & 12 & 13 & 13 & 14 & 64 \\
$\mathrm{~T}_{5}: 0.8 \mathrm{~g}(\mathrm{KMS}+$ Citric acid) & 13 & 13 & 12 & 14 & 13 & 65 \\
$\mathrm{~T}_{6}: 1.0 \mathrm{~g}(\mathrm{KMS}+$ Citric acid) & 15 & 14 & 14 & 15 & 15 & 73 \\
\hline Initial scores & 17 & 20 & 19 & 18 & 20 & 94 \\
\hline
\end{tabular}

KMS: Citric Acid @ 10:6 
The study inferred that, $\mathrm{SO}_{2}$ pads did not show positive effect on sensory characters such as colour, taste, texture, flavour and absence of defects in strawberry fruits under ambient condition of storage. The fruits treated with sulphur dioxide pad with various grams of KMS + citric acid had not recorded significant scores compared against initial score of 94 points (Table 5) (Pelayo et al., 2003). This might be due to high respiration and transpiration rates, high temperature, increased microbial infection, induce catabolic activity of strawberry fruits and had not control of loss of weight (Shin et al., 2008; Jouki and Khazaei, 2012; Srivastava and kumar, 2012).

The result revealed that, $\mathrm{SO}_{2}$ pad is not effective treatment for enhancement of shelf life of strawberry under ambient condition. This might be due to high temperature that sulphur gas would be released quickly from the pads and then remove from containers. Meanwhile high temperature caused chemical injured fruits' surface through sulphur dioxide gases at first stage of its releasing as strawberry has fleshy tissues without any protective skin.

Therefore high respiration and transpiration rates, and also high catabolic process occur and thus fruits may be affected through severe microbial infection within storage period (Shin et al., 2008).

The investigation, conclude that $\mathrm{SO}_{2}$ pad did not show significant effect on shelf life of strawberry fruits under ambient condition. Sulphur dioxide pads containing different concentrations of KMS + citric acid did not prevent postharvest decay and had not extended the shelf life of Dimonte strawberries under ambient condition, compared to shelf life of fruits in control. All the treatments including the control have decayed in four days at ambient storage.

\section{References}

Cordenunsi, B. R., Nascimento, J. R. O. and Lajolo, F. M. 2003. Physico- chemical changes related to quality of five strawberry fruit cultivars during cool storage, Food Chem., 83:167- 183.

Giampieri, F., Tulipani, S., Suarez, J. M. A., Quiles, J. L., Mezzetti, B. and Battino, M. 2012. The strawberry composition, nutritional quality and impact on human health, Nutrition, 28: 9 - 19.

Holcroft, D. M. and Kader, A.A. 1999. Controlled atmosphere induced changes in $\mathrm{pH}$ and organic acid metabolism may affect colour of stored strawberry fruit, Post-harvest boil. Technol., 17:19 - 30.

Jouki, M. and Khazaei, N. 2012. The effect of modified atmosphere packaging and calcium chloride dipping on the quality and shelf life of Kurdistan strawberry, Food Process Technol., 3 (10): 2 - 7.

Khezrzadeh, K., Baneh, H.D., Hassani, A., Abdollahi, R. and Rasoul, S. 2013. Effects of sulphur pads and ammi plant essential oil on storage life of grapevine (Vitis vinifera L) cv rash, Int. J. Agric. Crop Sci., 5 (20): 2447 - 2453.

Krishnan, P. 2001. Storage of fresh grapes by using $\mathrm{SO}_{2}$ generators, M. Sc. Thesis, Univ. Agric. Sci., Bangalore, 1- 7.

Nielsen, T. and Leufven, A. 2008. The effect of modified atmosphere packaging on the quality of Honeoye and korona strawberries, Food Chem., 107: 1053 1063.

Pelayo, C., Ebeler, S. E. and Kader, A. A. 2003. Postharvest life and flavor quality of three strawberry cultivars kept at $5^{\circ} \mathrm{C}$ in air or air $+20 \mathrm{kpa} \mathrm{CO}_{2}$, Post-harvest Biol. Technol., 27: $171-183$.

Prakash, M. B. S. 1997. Postharvest sanitization treatments on strawberry to prevent spoilage and maintain quality during storage, M.Sc. Thesis, Division of Horticulture, University of 
Agricultural Sciences, Bangalore, 1-8.

Rajesh, M.S. 1993. Development of grape guards for storage of fresh table grapes (Vitis vinifera L.). M Sc, Thesis, Univ. Agric. Sci., Bangalore, 17-28.

Samiullah, S., Sreenivas, K.N., shankarappa, T.H., Krishna, H.C. and Sadananda, G.K. 2015, Sulfur dioxide pads on enhancement of shelf life of strawberry Fragaria ananasa, Env. Ecol. 33 (4B): 1821-1826.

Shin, Y., Ryu, J.A., Liu, R.H., Nock, J.F. and Watkins, C.B. 2008. Harvest maturity, storage temperature and relative humidity affect fruit quality, antioxidant contents and activity, and inhibition of cell proliferation of strawberry fruit, Postharvest Biol. Technol., 49: 201 209.

Srivastava, R.P. and Kumar, S. 2012. Fruits and vegetable preservation. Important methods of analysis of fruits and vegetables and their products, IBDC Publishers, India. 353 - 364 .

Verma, L. R. and Joshi, V. K. 2006. Postharvest technology of fruits and vegetables, Indus Publishing Company, New Delhi. 1: 390 - 395.

Wang, S.Y. and Gao, H. 2013. Effect of chitosan based edible coating on antioxidant, antioxidant enzyme system, and postharvest fruit quality of strawberries (Fragaria ananassa Duch), Food Sci. Technol., 52: 71- 79.

Zhang, H., Wang, L., Dong, Y., Jaing, S., Cao, J. and Meng, R. 2007. Postharvest biological control of gray mould decay of strawberry with Rhodotorula glutinis, Biological Control., 40: 287- 292.

\section{How to cite this article:}

Sayed Samiullah Hakimi, K.N. Sreenivas, T.H. Shankarappa, H.C. Krishna and Sadananda, G.K. 2017. Effect of Sulphur Dioxide Pads on Enhancement of Shelf Life of Strawberry (Fragaria ananassa) under Ambient Condition. Int.J.Curr.Microbiol.App.Sci. 6(7): 2371-2377. doi: https://doi.org/10.20546/ijcmas.2017.607.339 